\title{
STUDY ON THE INFLUENCE OF WELDER'S FATIGUE ON THE QUALITY OF WELD LINES
}

\author{
DIANA LUNGU ${ }^{1}$, CAROL SCHNAKOVSZKY ${ }^{* 1}$, ALEXANDRU ACSINTE ${ }^{1}$, \\ EUGEN HERGHELEGIU ${ }^{1}$, CRINA RADU ${ }^{1}$ \\ “Vasile Alecsandri" University of Bacau, Calea Marasesti 157, Bacau, 600115, Romania
}

\begin{abstract}
In this paper a case study is presented, based on certain exercises applied to different welders, to evaluate the influence of welder's fatigue on the quality of welding. The performed test was aimed at evaluating the technical performance (the welding act) of subjects, as well as the accuracy of weld lines. Five modules of exercises were applied. The exercises of each module were various, they were of medium level, so that they were neither overburdened, nor unsolicited, because both situations could lead to accidents due to fatigue. A weld line was performed after each exercises' module. The visual quality of welding was appreciated according to the EN ISO 17637:2011 standard.
\end{abstract}

Keywords: welders' fatigue, quality of weld lines

\section{INTRODUCTION}

In carrying out the welding, special importance must be given to the position of performer during the movements, to the effort, because the way in which some movements are executed conditions the load of the whole body and, in particular, of the spine [1]. The main risk factors are: uncomfortable working positions, situations where the muscles contract and the human body is subjected to an increased mechanical effort; repetitive movements or in extended statistical positions, involving the same groups of joints and muscles; prolonged work without rest; vibrations in the hand-arm direction; lack of experience; improper clothing or equipment etc. The materialization of these factors may lead to musculoskeletal disorders, which usually affect the back, neck, shoulder and the upper limbs, but may also affect the lower limbs [2,3].

In Romania, the welding profession is between the first seven professions where the most professional diseases are registered [4]. A predominant osteo-musculo-articular effort is specific to this profession and, consequently, some degree of neuro - psychic and sensory effort intervenes, playing a major role of coordination and control both, on the effector locomotive system and on the cardiovascular and respiratory apparatus as well as on nervous system.

The aim of the case study presented in this paper was to:

- test the effort capacity of subjects, so that to get the highest possible performance which, in turn, lead to a higher efficiency and a higher productivity of the welding process;

- determine the types of errors and dysfunctions and their consequences on the subjects;

- test the subjects' resistance to intense and long-lasting efforts;

- test the subjects' possibility of switching from one activity to another;

- test the subjects' speed of adaption to new situations;

- test the resistance to the action of stressors;

*Corresponding author, email: $\underline{\text { scarol@ } \mathrm{ub} . \mathrm{ro}}$

(C) 2020 Alma Mater Publishing House 
- test the subjects' degree of impulsivity or restraint (the psychomotor balance), so that, based on the results, develop a prevention policy that include working conditions, influence factors related to the work environment and work organization.

\section{EXPERIMENTAL SETUP}

\subsection{Selected exercises}

The selected exercises are similar in structure to the act of welding, as we tried to challenge the neuro-motor components of each subject (six subjects). Five modules of exercises were applied (Table 1), structured in three phases:

- phase 1 - for „body heating”, including module 1 of exercises and welding at the end of module (a weld line of $150 \mathrm{~mm}$ );

- phase 2 - including modules II and III, welding between the two modules as well as at the end of module III (a weld line of $150 \mathrm{~mm}$ );

- phase 3 - including modules IV and V, welding between the two modules as well as at the end of module V (a weld line of $150 \mathrm{~mm}$ ).

Table 1. Designed modules of exercises.

\begin{tabular}{|c|c|c|c|c|c|c|c|}
\hline \multicolumn{8}{|c|}{ Module I - 1.30min (15 seconds each exercise) } \\
\hline Exercise 1 & \multicolumn{2}{|c|}{ Exercise 2} & Exercise 3 & Exercise 4 & \multicolumn{2}{|c|}{ Exercise 5} & Exercise 6 \\
\hline $\begin{array}{l}\text { beat up and } \\
\text { down with both } \\
\text { palms, standing } \\
\text { on the left foot }\end{array}$ & \multicolumn{2}{|c|}{$\begin{array}{l}\text { beat up and down } \\
\text { with both palms, } \\
\text { standing on the } \\
\text { right foot }\end{array}$} & $\begin{array}{l}\text { the left palm fixed, } \\
\text { beat from palms } \\
\text { from top to bottom, } \\
\text { sitting on left foot }\end{array}$ & $\begin{array}{c}\text { the right palm } \\
\text { fixed, beat from } \\
\text { palms from top to } \\
\text { bottom, sitting on } \\
\text { left foot }\end{array}$ & \multicolumn{2}{|c|}{$\begin{array}{l}\text { the right palm } \\
\text { fixed, beat from } \\
\text { palms from top to } \\
\text { bottom, sitting on } \\
\text { right foot }\end{array}$} & $\begin{array}{c}\text { the left palm } \\
\text { fixed, beat from } \\
\text { palms from top } \\
\text { to bottom, } \\
\text { sitting on right } \\
\text { foot }\end{array}$ \\
\hline \multicolumn{8}{|c|}{ Module II - 1min (15 seconds each exercise) } \\
\hline \multicolumn{2}{|c|}{ Exercise 1} & \multicolumn{2}{|r|}{ Exercise 2} & \multicolumn{2}{|c|}{ Exercise 3} & \multicolumn{2}{|r|}{ Exercise 4} \\
\hline \multicolumn{2}{|c|}{$\begin{array}{l}\text { the right palm fixed, beat } \\
\text { from palms from top to } \\
\text { bottom, the left eye closed, } \\
\text { sitting on left foot }\end{array}$} & \multicolumn{2}{|c|}{$\begin{array}{l}\text { the right palm fixed, beat from } \\
\text { palms from top to bottom, the } \\
\text { right eye closed, sitting on left } \\
\text { foot }\end{array}$} & \multicolumn{2}{|c|}{$\begin{array}{l}\text { the left palm fixed, beat from } \\
\text { palms from top to bottom, the } \\
\text { left eye closed, sitting on left } \\
\text { foot }\end{array}$} & \multicolumn{2}{|c|}{$\begin{array}{l}\text { the left palm fixed, beat } \\
\text { from palms from top to } \\
\text { bottom, the right eye closed, } \\
\text { sitting on left foot }\end{array}$} \\
\hline \multicolumn{8}{|c|}{ Module III - 1min (15 seconds each exercise) } \\
\hline \multicolumn{2}{|c|}{ Exercise 1} & \multicolumn{2}{|r|}{ Exercise 2} & \multicolumn{2}{|c|}{ Exercise 3} & \multicolumn{2}{|r|}{ Exercise 4} \\
\hline \multicolumn{2}{|c|}{$\begin{array}{l}\text { the right palm fixed, beat } \\
\text { from palms from top to } \\
\text { bottom, the left eye closed, } \\
\text { sitting on right foot }\end{array}$} & \multicolumn{2}{|c|}{$\begin{array}{l}\text { the right palm fixed, beat from } \\
\text { palms from top to bottom, the } \\
\text { right eye closed, sitting on } \\
\text { right foot }\end{array}$} & \multicolumn{2}{|c|}{$\begin{array}{l}\text { the left palm fixed, beat from } \\
\text { palms from top to bottom, the } \\
\text { left eye closed, sitting on right } \\
\text { foot }\end{array}$} & \multicolumn{2}{|c|}{$\begin{array}{l}\text { the left palm fixed, beat } \\
\text { from palms from top to } \\
\text { bottom, the right eye closed, } \\
\text { sitting on right foot }\end{array}$} \\
\hline \multicolumn{8}{|c|}{ Module IV - 1min (15 seconds each exercise) } \\
\hline \multicolumn{2}{|c|}{ Exercise 1} & \multicolumn{2}{|r|}{ Exercise 2} & \multicolumn{2}{|c|}{ Exercise 3} & & Exercise 4 \\
\hline \multicolumn{2}{|c|}{$\begin{array}{l}\text { opening and closing fist } \\
\text { with the pollicis inside and } \\
\text { outside, left eye closed }\end{array}$} & \multicolumn{2}{|c|}{$\begin{array}{l}\text { opening and closing fist with } \\
\text { alternative grip of pollicis } \\
\text { inside, right eye closed }\end{array}$} & \multicolumn{2}{|c|}{$\begin{array}{l}\text { opening and closing fist with } \\
\text { the pollicis inside and outside, } \\
\text { both eyes closed }\end{array}$} & $\begin{array}{l}\text { openi } \\
\text { with } \\
\text { pollic }\end{array}$ & $\begin{array}{l}\mathrm{g} \text { and closing fist } \\
\text { lternative grip of } \\
\text { inside, both eyes } \\
\text { closed }\end{array}$ \\
\hline \multicolumn{8}{|c|}{ Module V - 1min (15 seconds each exercise) } \\
\hline \multicolumn{2}{|c|}{ Exercise 1} & \multicolumn{2}{|r|}{ Exercise 2} & \multicolumn{2}{|c|}{ Exercise 3} & & Exercise 4 \\
\hline \multicolumn{2}{|c|}{$\begin{array}{l}\text { standing on the left foot, } \\
\text { opening and closing fist } \\
\text { with the pollicis inside and } \\
\text { outside, left eye closed }\end{array}$} & \multicolumn{2}{|c|}{$\begin{array}{l}\text { standing on the left foot, } \\
\text { opening and closing fist with } \\
\text { the pollicis inside and outside, } \\
\text { right eye closed }\end{array}$} & \multicolumn{2}{|c|}{$\begin{array}{l}\text { standing on the right foot, } \\
\text { opening and closing fist with } \\
\text { the pollicis inside and outside, } \\
\text { left eye closed }\end{array}$} & $\begin{array}{r}\text { standi } \\
\text { open } \\
\text { with th } \\
\text { outsic }\end{array}$ & $\begin{array}{l}\mathrm{g} \text { on the right foot, } \\
\mathrm{g} \text { and closing fist } \\
\text { pollicis inside and } \\
\text {, right eye closed }\end{array}$ \\
\hline
\end{tabular}

Each module consisted in various exercises, with a medium complexity, so that they were neither overburdened, nor unsolicited, because both situations could lead to accidents due to fatigue. Rules and instructions were given clearly and exemplified to each subject, so that to ensure their safety and security, as well as to obtain good quality weld lines. 
In establishing the number of modules and the number of exercises for each module, it was taken into account, on the one hand, the principle of balance between the volume and complexity of exercises and, on the other hand, the subject ability to cope with the exercises' execution, as well as the welding process performed after the exercises.

The initial carried out testing was aimed at evaluating both, the technical performance (the welding act) of each subject as well as the accuracy of realized weld lines. The complexity of exercises was increased in modules 4 and 5 , the accent being on the neuro-muscular coordination, materialized in:

- hand - eye coordination;

- hand - hand coordination;

- hand - foot coordination;

- eye - hand - foot coordination;

- eye - foot coordination.

\subsection{Used equipment and material}

The experiments were performed using a SAF MIG 400 BLX, MIG/MAG welding machine, with a SAF FRO DV $44 \mathrm{X}$ wire dosing system and a CITOFLUX R00C electrode [5]. The weld lines were made on a S235 JR steel plate. This steel has a general use in industry, to manufacture elements of metallic constructions such as bridges, road and rail, tanks, pillars, elements of load-bearing structures of machines, chains, welded nets for reinforced concrete etc., welded or joined by other processes.

\section{RESULTS AND DISCUSSION}

The performance of the six subjects related to the execution of exercises specific to the five modules as well as to the act of welding performed after each module is presented in the Table 2 - Table 6.

Table 2. Subjects' performance related to the exercises of Module 1 (1.30 min, 15 seconds each exercise) and the welding process performed at the end of module.

\begin{tabular}{|c|c|c|c|c|c|c|}
\hline Exercises/Subjects & Subject 1 & Subject 2 & Subject 3 & Subject 4 & Subject 5 & Subject 6 \\
\hline Exercise 1 & \multicolumn{6}{|c|}{ All subjects executed it correctly } \\
\hline Exercise 2 & \multicolumn{6}{|c|}{ All subjects executed it correctly } \\
\hline Exercise 3 & $\begin{array}{l}\text { correct } \\
\text { execution }\end{array}$ & $\begin{array}{l}\text { imbalance at } \\
\text { the second } 10\end{array}$ & $\begin{array}{l}\text { imbalance at the } \\
\text { sec. } 14, \text { balance } \\
\text { restored }\end{array}$ & $\begin{array}{c}\text { imbalance at the } \\
\text { sec. } 13, \text { balance } \\
\text { restored }\end{array}$ & $\begin{array}{r}\text { correct } \\
\text { execution }\end{array}$ & $\begin{array}{r}\text { correct } \\
\text { execution }\end{array}$ \\
\hline Exercise 4 & \multicolumn{6}{|c|}{ All subjects executed it correctly } \\
\hline Exercise 5 & \multicolumn{6}{|c|}{ All subjects executed it correctly } \\
\hline Exercise 6 & $\begin{array}{c}\text { correct } \\
\text { execution }\end{array}$ & $\begin{array}{c}\text { correct } \\
\text { execution }\end{array}$ & $\begin{array}{c}\text { correct } \\
\text { execution }\end{array}$ & $\begin{array}{c}\text { correct } \\
\text { execution }\end{array}$ & $\begin{array}{l}\text { imbalance at the } \\
\text { sec. } 13 \text {, balance } \\
\text { restored }\end{array}$ & $\begin{array}{l}\text { imbalance at } \\
\text { the sec. } 10, \\
\text { balance } \\
\text { restored }\end{array}$ \\
\hline Welding process & $\begin{array}{l}\text { performed in } 36 \\
\text { sec }\end{array}$ & $\begin{array}{l}\text { performed in } 34 \\
\text { sec }\end{array}$ & $\begin{array}{l}\text { performed in } \\
21.15 \mathrm{sec}\end{array}$ & $\begin{array}{l}\text { performed in } \\
22.22 \mathrm{sec}\end{array}$ & $\begin{array}{l}\text { performed in } \\
22.48 \mathrm{sec}\end{array}$ & $\begin{array}{r}\text { performed in } \\
22.67 \mathrm{sec}\end{array}$ \\
\hline
\end{tabular}

Table 3. Subjects' performance related to the exercises of Module 2 ( $1 \mathrm{~min}, 15$ seconds each exercise) and the welding process performed at the end of module.

\begin{tabular}{|c|c|c|c|c|c|c|}
\hline Exercises/Subjects & Subject 1 & Subject 2 & Subject 3 & Subject 4 & Subject 5 & Subject 6 \\
\hline Exercise 1 & $\begin{array}{c}\text { a slight } \\
\text { imbalance }\end{array}$ & $\begin{array}{c}\text { correct } \\
\text { execution }\end{array}$ & $\begin{array}{c}\text { correct } \\
\text { execution }\end{array}$ & $\begin{array}{c}\text { imbalance at the } \\
\text { sec. } 7, \text { balance } \\
\text { restored }\end{array}$ & $\begin{array}{c}\text { imbalance at the } \\
\text { sec. } 3, \text { balance } \\
\text { restored }\end{array}$ & $\begin{array}{c}\text { correct } \\
\text { execution }\end{array}$ \\
\hline Exercise 2 & $\begin{array}{r}\text { correct } \\
\text { execution }\end{array}$ & $\begin{array}{c}\text { a slight } \\
\text { imbalance at } \\
\text { the end }\end{array}$ & $\begin{array}{l}\text { imbalance at the } \\
\text { sec. } 10 \text {, stopped } \\
\text { the exercise }\end{array}$ & $\begin{array}{r}\text { correct } \\
\text { execution }\end{array}$ & $\begin{array}{r}\text { correct } \\
\text { execution }\end{array}$ & $\begin{array}{c}\text { imbalance at the } \\
\text { sec. } 7, \text { balance } \\
\text { restored }\end{array}$ \\
\hline Exercise 3 & $\begin{array}{r}\text { correct } \\
\text { execution }\end{array}$ & $\begin{array}{c}\text { two } \\
\text { imbalances, } \\
\text { (sec. } 6 \text { and at } \\
\text { the end) }\end{array}$ & $\begin{array}{c}\text { a slight } \\
\text { imbalance at the } \\
\text { end }\end{array}$ & $\begin{array}{l}\text { failed to } \\
\text { coordinate } \\
\text { the eye, hand } \\
\text { and foot on } \\
\text { the same side } \\
\text { (left). }\end{array}$ & $\begin{array}{l}\text { imbalance at the } \\
\text { sec. } 7, \text { balance } \\
\text { restored }\end{array}$ & $\begin{array}{c}\text { slight } \\
\text { imbalances at } \\
\text { the sec. } 4,8 \text { and } \\
11 \text {, balance } \\
\text { restored }\end{array}$ \\
\hline Exercise 4 & $\begin{array}{r}\text { correct } \\
\text { execution }\end{array}$ & $\begin{array}{c}\text { two } \\
\text { imbalances, } \\
\text { (sec. } 11 \text { and at } \\
\text { the end) }\end{array}$ & $\begin{array}{l}\text { imbalance at the } \\
\text { sec. } 7, \text { stopped } \\
\text { the exercise }\end{array}$ & $\begin{array}{r}\text { correct } \\
\text { execution }\end{array}$ & $\begin{array}{c}\text { imbalance at the } \\
\text { sec. } 9, \text { balance } \\
\text { restored }\end{array}$ & $\begin{array}{c}\text { slight } \\
\text { imbalances at } \\
\text { the sec. } 6 \text { and } 11 \text {, } \\
\text { balance restored }\end{array}$ \\
\hline Welding process & $\begin{array}{r}\text { performed in } \\
35 \mathrm{sec} .\end{array}$ & $\begin{array}{r}\text { performed in } \\
35.71 \mathrm{sec} \\
\end{array}$ & $\begin{array}{c}\text { performed in } 16 \\
\text { sec. }\end{array}$ & $\begin{array}{l}\text { performed in } \\
22.64 \mathrm{sec}\end{array}$ & $\begin{array}{l}\text { performed in } \\
22.32 \mathrm{sec}\end{array}$ & $\begin{array}{c}\text { performed in } \\
20.61 \mathrm{sec}\end{array}$ \\
\hline
\end{tabular}


Table 4. Subjects' performance related to the exercises of Module 3 ( $1 \mathrm{~min}, 15$ seconds each exercise) and the welding process performed at the end of module.

\begin{tabular}{|c|c|c|c|c|c|c|}
\hline Exercises/Subjects & Subject 1 & Subject 2 & Subject 3 & Subject 4 & Subject 5 & Subject 6 \\
\hline Exercise 1 & \multicolumn{6}{|c|}{ All subjects executed it correctly } \\
\hline Exercise 2 & $\begin{array}{r}\text { correct } \\
\text { execution }\end{array}$ & $\begin{array}{c}\text { imbalance at } \\
\text { sec. } 14\end{array}$ & $\begin{array}{c}\text { imbalance at } \\
\text { the sec.7, } \\
\text { balance } \\
\text { restored }\end{array}$ & $\begin{array}{r}\text { correct } \\
\text { execution }\end{array}$ & $\begin{array}{l}\text { imbalance at } \\
\text { the sec. } 6 \text {, } \\
\text { balance } \\
\text { restored }\end{array}$ & $\begin{array}{c}\text { imbalance at } \\
\text { the sec. } 3 \text {, } \\
\text { balance } \\
\text { restored }\end{array}$ \\
\hline Exercise 3 & $\begin{array}{r}\text { correct } \\
\text { execution }\end{array}$ & $\begin{array}{c}\text { signs of } \\
\text { fatigue, } \\
\text { couldn't } \\
\text { coordinate } \\
\text { well hand and } \\
\text { foot }\end{array}$ & $\begin{array}{c}\text { signs of } \\
\text { fatigue, } \\
\text { couldn't } \\
\text { coordinate } \\
\text { well eye and } \\
\text { foot }\end{array}$ & $\begin{array}{c}\text { lack of } \\
\text { coordination } \\
\text { between eye } \\
\text { and hand, } \\
\text { imbalance at } \\
\text { the sec. } 14\end{array}$ & $\begin{array}{c}\text { imbalance at } \\
\text { the sec. } 7 \text {, } \\
\text { balance } \\
\text { restored }\end{array}$ & $\begin{array}{c}\text { imbalance at } \\
\text { the sec. } 11 \text {, } \\
\text { balance } \\
\text { restored }\end{array}$ \\
\hline Exercise 4 & $\begin{array}{r}\text { imbalance at } \\
\text { the sec. } 13\end{array}$ & $\begin{array}{l}\text { imbalance at } \\
\text { the sec. } 13\end{array}$ & $\begin{array}{l}\text { imbalance at } \\
\text { the sec. } 11 \text {, } \\
\text { stopped the } \\
\text { exercise }\end{array}$ & $\begin{array}{l}\text { signs of } \\
\text { fatigue, lack } \\
\text { of coordin. } \\
\text { between eye } \\
\text { and hand }\end{array}$ & $\begin{array}{c}\text { imbalances } \\
\text { at the sec. } 9 \text {, } \\
12 \text { and } 14\end{array}$ & $\begin{array}{c}\text { imbalance at } \\
\text { the sec.9, } \\
\text { hardly } \\
\text { balance } \\
\text { restored }\end{array}$ \\
\hline Welding process & $\begin{array}{r}\text { performed in } \\
36 \mathrm{sec} .\end{array}$ & $\begin{array}{c}\text { performed in } \\
35.61 \mathrm{sec}\end{array}$ & $\begin{array}{c}\text { performed in } \\
17.65 \mathrm{sec}\end{array}$ & $\begin{array}{r}\text { performed in } \\
26.27 \mathrm{sec} \\
\end{array}$ & $\begin{array}{c}\text { performed in } \\
27 \mathrm{sec}\end{array}$ & $\begin{array}{c}\text { performed in } \\
19.08 \mathrm{sec} \\
\end{array}$ \\
\hline
\end{tabular}

Table 5. Subjects' performance related to the exercises of Module 4 ( $1 \mathrm{~min}, 15$ seconds each exercise) and the welding process performed at the end of module

\begin{tabular}{|c|c|c|c|c|c|c|}
\hline Exercises/Subjects & Subject 1 & Subject 2 & Subject 3 & Subject 4 & Subject 5 & Subject 6 \\
\hline Exercise 1 & $\begin{array}{c}\text { correct } \\
\text { execution }\end{array}$ & $\begin{array}{c}\text { correct } \\
\text { execution }\end{array}$ & $\begin{array}{c}\text { correct } \\
\text { execution }\end{array}$ & $\begin{array}{c}\text { cannot } \\
\text { keep the left } \\
\text { eye closed }\end{array}$ & $\begin{array}{c}\text { slight } \\
\text { tremors of } \\
\text { hands, } \\
\text { difficulty in } \\
\text { coordination }\end{array}$ & $\begin{array}{c}\text { a slightly } \\
\text { difficulty in } \\
\text { coordination }\end{array}$ \\
\hline Exercise 2 & $\begin{array}{r}\text { correct } \\
\text { execution }\end{array}$ & $\begin{array}{c}\text { correct } \\
\text { execution }\end{array}$ & $\begin{array}{c}\text { correct } \\
\text { execution }\end{array}$ & $\begin{array}{l}\text { a slightly } \\
\text { difficulty in } \\
\text { coordination }\end{array}$ & $\begin{array}{c}\text { closed both } \\
\text { eyes }\end{array}$ & $\begin{array}{c}\text { lack of } \\
\text { coordination } \\
\text { between eye } \\
\text { and hand }\end{array}$ \\
\hline Exercise 3 & $\begin{array}{l}\text { fail to execute } \\
\text { (could not } \\
\text { concentrate) }\end{array}$ & $\begin{array}{c}\text { correct } \\
\text { execution }\end{array}$ & $\begin{array}{c}\text { slight } \\
\text { tremors of } \\
\text { hands }\end{array}$ & $\begin{array}{c}\text { correct } \\
\text { execution }\end{array}$ & $\begin{array}{c}\text { correct } \\
\text { execution }\end{array}$ & $\begin{array}{c}\text { correct } \\
\text { execution }\end{array}$ \\
\hline Exercise 4 & $\begin{array}{l}\text { fail to execute } \\
\text { (could not } \\
\text { concentrate) }\end{array}$ & $\begin{array}{l}\text { failed to } \\
\text { focus on } \\
\text { catching the } \\
\text { pollicis } \\
\text { alternatively }\end{array}$ & $\begin{array}{c}\text { correct } \\
\text { execution }\end{array}$ & $\begin{array}{c}\text { correct } \\
\text { execution }\end{array}$ & $\begin{array}{c}\text { correct } \\
\text { execution }\end{array}$ & $\begin{array}{c}\text { correct } \\
\text { execution }\end{array}$ \\
\hline Welding process & $\begin{array}{c}\text { performed in } \\
32 \mathrm{sec} .\end{array}$ & $\begin{array}{c}\text { performed in } \\
36.22 \mathrm{sec}\end{array}$ & $\begin{array}{c}\text { performed } \\
\text { in } 13.69 \mathrm{sec} .\end{array}$ & $\begin{array}{l}\text { performed } \\
\text { in } 23.59 \mathrm{sec}\end{array}$ & $\begin{array}{l}\text { performed } \\
\text { in } 30.05 \mathrm{sec}\end{array}$ & $\begin{array}{c}\text { performed in } \\
18 \mathrm{sec}\end{array}$ \\
\hline
\end{tabular}

Table 6. Subjects' performance related to the exercises of Module 5 ( $1 \mathrm{~min}, 15$ seconds each exercise) and the welding process performed at the end of module

\begin{tabular}{|c|c|c|c|c|c|c|}
\hline Exercises/Subjects & Subject 1 & Subject 2 & Subject 3 & Subject 4 & Subject 5 & Subject 6 \\
\hline Exercise 1 & $\begin{array}{l}\text { correct } \\
\text { execution }\end{array}$ & $\begin{array}{c}\text { lack of } \\
\text { coordination } \\
\text { eye - hand - } \\
\text { foot } \\
\end{array}$ & $\begin{array}{l}\text { imbalance at the } \\
\text { sec. } 5 \text {, balance } \\
\text { restored }\end{array}$ & $\begin{array}{l}\text { difficulty in } \\
\text { coordination }\end{array}$ & $\begin{array}{l}\text { tremors of } \\
\text { hands, } \\
\text { difficulty in } \\
\text { coordination }\end{array}$ & $\begin{array}{l}\text { difficulty in } \\
\text { coordination }\end{array}$ \\
\hline Exercise 2 & $\begin{array}{r}\text { correct } \\
\text { execution }\end{array}$ & $\begin{array}{c}\text { lack of } \\
\text { coordination } \\
\text { eye - hand - } \\
\text { foot } \\
\end{array}$ & correct execution & $\begin{array}{l}\text { slight difficulty } \\
\text { in coordination }\end{array}$ & $\begin{array}{c}\text { tremors of } \\
\text { hands, stopped } \\
\text { the exercises at } \\
\text { the sec. } 13\end{array}$ & $\begin{array}{l}\text { difficulty in } \\
\text { coordination }\end{array}$ \\
\hline Exercise 3 & $\begin{array}{c}\text { correct } \\
\text { execution }\end{array}$ & $\begin{array}{c}\text { lack of } \\
\text { coordination } \\
\text { eye - hand - } \\
\text { foot } \\
\end{array}$ & $\begin{array}{l}\text { slight imbalances } \\
\text { at the sec. } 8 \text { and } \\
14\end{array}$ & $\begin{array}{l}\text { imbalance at } \\
\text { the sec. } 3 \text {, } \\
\text { balance } \\
\text { restored }\end{array}$ & $\begin{array}{c}\text { tremors of } \\
\text { hands, } \\
\text { imbalances at } \\
\text { the sec. } 12\end{array}$ & $\begin{array}{c}\text { closed both } \\
\text { eyes }\end{array}$ \\
\hline Exercise 4 & $\begin{array}{c}\text { slight } \\
\text { imbalances, } \\
\text { lack of } \\
\text { concentration }\end{array}$ & $\begin{array}{c}\text { lack of } \\
\text { coordination } \\
\text { eye }- \text { hand - } \\
\text { foot }\end{array}$ & $\begin{array}{l}\text { slight imbalances } \\
\text { at the sec. } 4 \text { and } \\
9, \text { stopped } \\
\text { exercise at sec. } \\
13\end{array}$ & $\begin{array}{l}\text { imbalance at } \\
\text { the sec. } 6, \\
\text { balance } \\
\text { restored }\end{array}$ & $\begin{array}{l}\text { imbalance at } \\
\text { the sec.7, } \\
\text { difficulty in } \\
\text { balance } \\
\text { restored }\end{array}$ & $\begin{array}{c}\text { closed both } \\
\text { eyes }\end{array}$ \\
\hline
\end{tabular}




\section{CONCLUSIONS}

By analysing the capacity of subjects to perform the five modules of physical exercises and their effect on the quality of welding, the following aspects were remarked:

- $\quad$ subject no. 1 (56 years old, 38 years of experience) managed to correctly execute the exercises of the first 3 modules, but he encountered some difficulties in performing exercises from module no. 4 , justifying that he cannot perform the exercises with closed eyes; at module no. 5, the phenomenon of fatigue appeared, manifested by lack of concentration and slight imbalances. Regarding the appearance of the weld lines, they have an inclination angle between $1^{\circ}$ and $5^{\circ}$. The first weld line was broken at about $130 \mathrm{~mm}$ (Figure 1a).

- $\quad$ subject no. 2 (29 years old, 2 years of experience) had some imbalances during the execution of exercises and even he did not manage to do some of them. The performed weld lines have nonuniformities and some of them are curved (Figure 1b);

- $\quad$ subject no. 3 (51 years old, 33 years of experience) mostly performed the exercises with slight imbalances; he had a correct execution of the exercises with closed eyes. The first 3 weld lines have an inclination angle between $2^{\circ}$ and $5^{\circ}$; the first weld line presents at the top a curvature of $21 \mathrm{~mm}$ while the weld line no. 4 shows a curvature with a radius of $286 \mathrm{~mm}$. The weld line no. 2, has the starting point well below to the starting line (Figure 1c);

- $\quad$ subject no. 4 (26 years old, 5 years of experience) performed the exercises with slight imbalances, failing to coordinate the eye-hand movements. The first and fifth weld lines have an angle of $1^{\circ}-2^{\circ}$ while the weld lines no. 3 and 4 present curves with radii between $346 \mathrm{~mm}$ and $375 \mathrm{~mm}$. The weld line no. 2 was executed properly, presenting a slight narrowing toward the end (Figure 1d);

- $\quad$ subject no. 5 (48 years old, 30 years of experience) performed the exercises with imbalances, slight tremors of hands, showing slight signs of fatigue. Instead of these, the weld lines were executed right, having slight non-uniformities; at the first weld line there is a slight $3^{\circ}$ inclination (Figure 1e);

- $\quad$ subject no. 6 (50 years old, 32 years of experience) performed correctly some exercises, especially form module no.1, but generally he manifested imbalances, impossibility to do the exercises with one eye closed, giving signs of fatigue towards the end. Some weld lines have inclinations of maximum $2^{\circ}$, the other have curvatures. The weld line no. 5 was executed on a smaller length (Figure 1f).

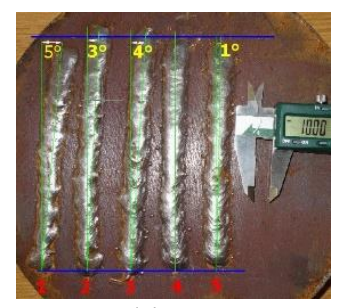

a. subject no. 1

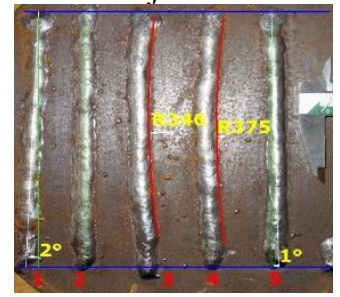

d. subject no. 4

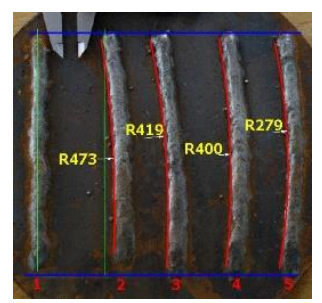

b. subject no. 2

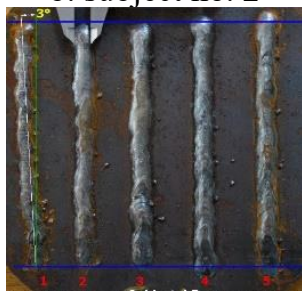

e. subject no. 5

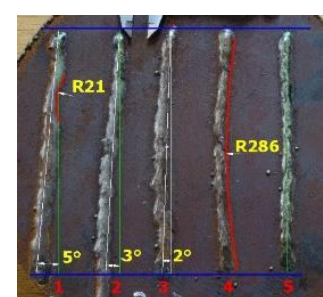

c. subject no. 3

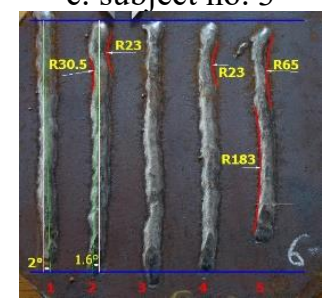

f. subject no. 6

Fig. 1. Weld lines performed by the six subjects.

\section{REFERENCES}

[1] Iorgulescu, C., Iliescu, C., Manipularea manuala a maselor, sursa de afectiuni musculo-scheletice, Lucrarile conferintei saptamana europeana a securitatii si sanatatii in munca, 2007, p. 8-15.

[2] Acsinte, A., Eftene, A., Milon, A., Lupescu, L., Improving ankle and knee joint stability. Proprioceptive Balancefit Discs Drills, XLibris Corporation, USA, 2010.

[3] Afra, R., Schepsis, A., Addressing patellofemoral pathology: Biomechanics and classification, Journal of Musculoskeletal Medicine, vol. 25, no. 6, 2008, p. 297-300.

[4] Calugareanu, L.D., Popescu, F.S., Morbiditatea profesionala in Romania, Institutul Naţional de Sanatate Publica, Bucuresti, 2017, p.1-6.

[5] Vasile, I., Utilajul si tehnologia sudarii, EDP Bucuresti, 1990. 